\title{
Record of Decision Remedial Alternative Selection for the Central Shops Burning/Rubble Pit (631-6G)
}

by

E. Palmer

Westinghouse Savannah River Company

Savannah River Site

Aiken, South Carolina 29808

This paper was prepared in connection with work done under the above contract number with the U. S.

Department of Energy. By acceptance of this paper, the publisher and/or recipient acknowledges the U.S. Government's right to retain a nonexclusive, royalty-free license in and to any copyright covering this paper, along with the right to reproduce and to authorize others to reproduce all or part of the copyrighted paper.

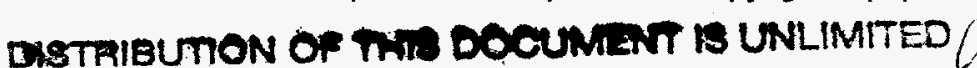




\section{DISCLAIMER}

This report was prepared as an account of work sponsored by an agency of the United States Government. Neither the United States Government nor any agency thereof, nor any of their employees, makes any warranty, express or implied, or assumes any legal liability or responsibility for the accuracy, completeness, or usefulness of any information, apparatus, product, or process disclosed, or represents that its use would not infringe privately owned rights. Reference herein to any specific commercial product, process, or service by trade name, trademark, manufacturer, or otherwise does not necessarily constitute or imply its endorsement, recommendation, or favoring by the United States Government or any agency thereof. The views and opinions of authors expressed herein do not necessarily state or reflect those of the United States Government or any agency thereof.

This report has been reproduced directly from the best available copy.

Available to DOE and DOE contractors from the Office of Scientific and Technical Information, P. O. Box 62, Oak Ridge, TN 37831; prices available from (423) 576-8401.

Available to the public from the National Technical Information Service, U. S. Department of Commerce, 5285 Port Royal Road, Springfield, VA 22161. 


\section{DISCLAIMER}

Portions of this document may be illegible electronic image products. Images are produced from the best available original document. 


\section{United States Department of Energy}

Savannah River Site

\section{Record of Decision \\ Remedial Alternative Selection for the Central Shops Burning/Rubble Pit (631-6G) (U)}

WSRC-RP-96-873

Revision 1

April 1997

Westinghouse Savannah River Company

Savannah River Site

Aiken, SC 29808

Prepared for the U. S. Department of Energy under Contract No. DE-AC09-96-SR18500

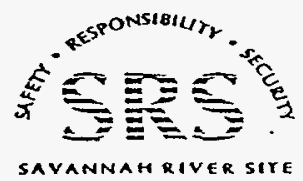


Printed in the United States of America

Prepared for

U. S. Department of Energy and

Westinghouse Savannah River Company Aiken, South Carolina 


\section{RECORD OF DECISION \\ REMEDIAL ALTERNATIVE SELECTION \\ FOR THE CENTRAL SHOPS BURNING/RUBBLE PIT (631-6G) (U)}

WSRC-RP-96-873

Revision 1

April 1997

Savannah River Site

Aiken, South Carolina

Prepared by:

Westinghouse Savannah River Company

for the

U. S. Department of Energy Under Contract DE-AC09-96SR18500

Savannah River Operations Office.

Aiken, South Carolina 
This page intentionally left blank. 


\section{DECLARATION FOR THE RECORD OF DECISION}

\section{Unit Name and Location}

Central Shops Burning/Rubble Pit (631-6G)

Savannah River Site

Aiken, South Carolina

The Central Shops Burning/Rubble Pit (631-6G) (BRP6G) is listed as a Resource Conservation and Recovery Act (RCRA) 3004(u) solid waste management unit/Comprehensive Environmental Response, Compensation, and Liability Act (CERCLA) unit in Appendix C of the Federal Facility Agreement (FFA) for the Savannah River Site (SRS).

\section{Statement of Basis and Purpose}

This decision document presents the selected remedial alternative for the BRP6G located at the SRS in Aiken, South Carolina. The selected alternative was developed in accordance with CERCLA, as amended, and to the extent practicable, the National Oil and Hazardous Substances Pollution Contingency Plan (NCP). This decision is based on the Administrative Record File for this specific RCRA/CERCLA unit.

\section{Description of the Selected Remedy}

The selected remedy for BRP6G is No Action. Other remedial alternatives for this unit were not considered because the risk levels fall within the risk range designated as requiring a risk management decision for all potential future receptors. The risk levels were developed in the Baseline Risk Assessment (BRA), which considered both the future residential and future industrial use scenarios. The cumulative soil related risks for the future residential land use scenario are less than one excess cancer in one hundred thousand $\left(1 \times 10^{-5}\right)$. In the future industrial land use scenario, all of the soil related risks are below $1 \times 10^{-6}$. The expected future use of this area is industrial. The South Carolina Department of Health and Environmental control has modified the SRS RCRA permit to incorporate the selected remedy.

In the future residential land use scenario, the contaminants that contributed to the risk were arsenic, beryllium, iron, octachlorodibenzo-p-dioxin (OCDD), and polychlorinated biphenyl (PCB) 1254 . Of these the concentrations of arsenic, beryllium, iron, and OCDD were not significantly elevated with respect to unitspecific background levels. The only risk directly attributable to the pit soil is $2 \times 10^{-6}$ due to PCB-1254 via ingestion of produce grown on-site. The maximum concentration of PCB-1254 detected in the pit was 0.115 $\mathrm{mg} / \mathrm{kg}$, approximately $10 \%$ of the residential action level for PCBs of $1 \mathrm{mg} / \mathrm{kg}$ (EPA, 1990). Drinking water standards for groundwater were exceeded in one well, on one occasion, for two compounds. Since these results were not reproducible in subsequent sampling, the exceedances are considered to be atypical and not unit related. Therefore, no action is appropriate.

If the property is ever transferred to non-federal ownership, the U. S. Government will create a deed for the new property owner which will contain information in compliance with CERCLA 120 (h). The deed shall include notification disclosing former waste management and disposal activities as well as remedial actions taken at the site. The deed notification shall, in perpetuity, notify any potential purchaser that the property has been used for the management and disposal of construction debris and other materials, including hazardous substances. In addition, if the site is ever transferred to non-federal ownership, a survey plat of the area will be prepared, certified by a professional land surveyor, and recorded with the appropriate county agency. 


\section{Statutory Determination}

Based on the BRP6G Resource Conservation and Recovery Act (RCRA) Facility Investigation/Remedial Investigation (RFI/RI) Report and the Baseline Risk Assessment, the BRP6G poses no significant risk to the environment and to human health. It is, therefore, proposed that No Action be performed for the BRP6G. The selected remedy is protective of human health and the environment and complies with Federal and State requirements that are legally applicable or relevant and appropriate to the remedial action.

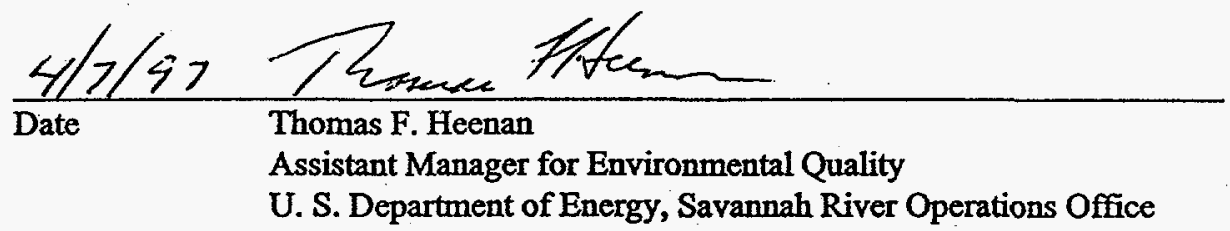

Date John H. Hankinson, Jr. Regional Administrator

U. S. Environmental Protection Agency

Date

R. Lewis Shaw

Deputy Commissioner

Environmental Quality Control

South Carolina Department of Health and Environmental Control 


\section{DECISION SUMMARY \\ REMEDIAL ALTERNATIVE SELECTION \\ FOR THE CENTRAL SHOPS BURNING/RUBBLE PIT (631-6G) (U)}

WSRC-RP-96-873

Revision 1

April 1997

Savannah River Site

Aiken, South Carolina

Prepared by:

Westinghouse Savannah River Company

for the

U. S. Department of Energy Under Contract DE-AC09-96SR18500

Savannah River Operations Office

Aiken, South Carolina 
This page intentionally left blank. 


\section{DECISION SUMMARY \\ TABLE OF CONTENTS}

\section{Section}

Declaration for the Record Of Decision

I.

Site And Operable Unit Name, Location, And Description . 1

II.

Operable Unit History And Compliance History .

III. Highlights Of Community Participation ....................................................................... 4

IV. $\quad$ Scope And Role Of Operable Unit Within The Site Strategy...............................................5

V. $\quad$ Summary Of Operable Unit Characteristics .......................................................................

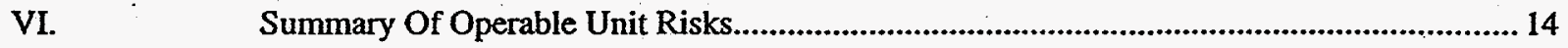

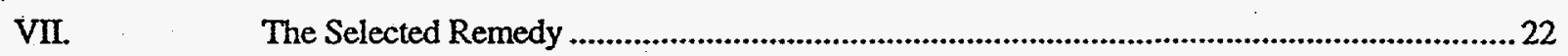

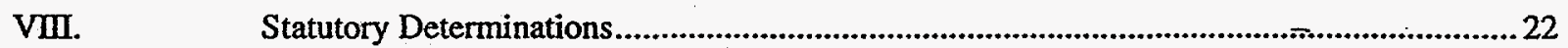

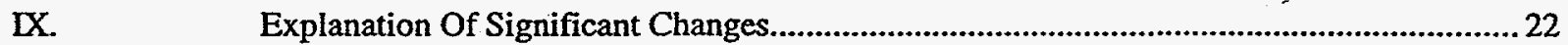

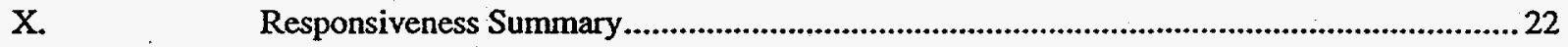

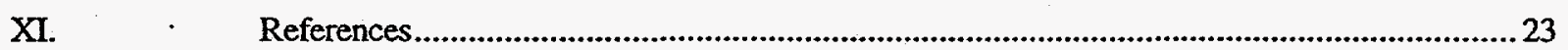

Appendix A

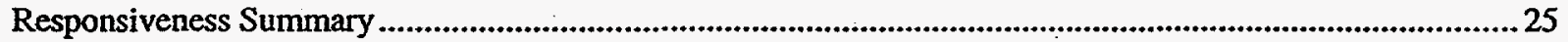

\section{List of Figures}

Figure 1 Location of BRP6G at the Savannah River Site ................................................................. 2

Figure 2 Location of BRP6G in the Central Shops Area of SRS........................................................... 3

Figure 3 Potentiometric Surface of the Water Table (Aquifer Unit IIB) at the BRP6G .......................7

Figure 4 Complete Characterization of the 1994 BRP6G Sampling Plan ............................................ 8

Figure $5 \quad$ Conceptual Site Model for Soil Risks for Current Groundwater Sampler and Current Material Yard Worker ..................................................................................................16

Figure 6 Conceptual Site Model for Soil Risks for Hypothetical Future Industrial Workers............... 17

Figure $7 \quad$ Conceptual Site Model for Soil Risks for Hypothetical Future Residents, Adult and Child Only

Table 1 Analytes and COPCs in Surface Soil (0-2 ft) Used in Calculations of Risk \& Hazard 10

Table 2 Analytes and COPCs in Shallow Subsurface Soil (0-5 ft) Used in Calculations of Risk \& Hazard

Table 3 Average Soil Concentrations of SSCs and COPCs Compared to Soil Screening Levels 


\section{SITE AND OPERABLE UNIT NAME, LOCATION, AND DESCRIPTION}

SRS occupies approximately 800 square kilometers ( 310 square miles) of land adjacent to the Savannah River, principally in Aiken and Barnwell counties of South Carolina. SRS is a secured U.S. Government facility with no permanent residents. SRS is located approximately 40 kilometers ( 25 miles) southeast of Augusta, Georgia and 32 kilometers (20 miles) south of Aiken, South Carolina.

SRS is owned by the U.S. Department of Energy (DOE). Management and operating services are provided by Westinghouse Savannah River Company (WSRC). SRS has historically produced tritium, plutonium, and other special nuclear materials for national defense.

BRP6G is located in the Central Shops Area near the center of the SRS (Figure 1). Figure 2 shows the relative location of $B R P 6 G$ with respect to Central Shops Area facilities. The BRP6G Solid Waste Management Unit is on the southeastern side of a divide that separates the drainage basins of the Pen Branch Creek [approximately $1.6 \mathrm{~km}$ (1 mile) to the southeast] and Fourmile Branch [approximately $4 \mathrm{~km}$ ( 2.5 mile) to the northwest]. The ground elevation is approximately $88.4 \mathrm{~m}$ (290 feet) above mean sea level. Surface drainage is southward to an unnamed tributary of Pen Branch.

\section{OPERABLE UNTT HISTORY AND COMPLIANCE HISTORY}

\section{Operable Unit History}

The BRP6G operated from 1951 through 1955 for the disposal and burning of waste materials. The unit consisted of a shallow unlined excavation, approximately $3 \mathrm{~m}$ (10 ft) deep. Historical records indicated that the disposal area at the BRP6G was

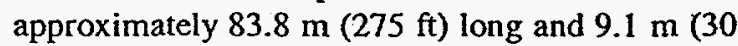
$\mathrm{ft}$ ) wide. A ground penetrating radar survey indicated that most of the soil in this area was undisturbed. This survey detected two areas of disturbed soil which could have been disposal sites. The largest area (Zone 1) is rectangular in shape and is approximately $6.1 \mathrm{~m}(20 \mathrm{ft})$ wide by $54.86 \mathrm{~m}$ (180 ft) long. A second area of disturbed soil (Zone 2) forms an ellipse approximately $6.1 \mathrm{~m}$ (20 ft) wide by $12.2 \mathrm{~m}$ (40 ft) long. The GPR survey did not find buried waste within the smaller disturbed soil area. This smaller disturbed soil area was likely a borrow pit used to provide waste cover.

Materials believed to be disposed of in the pit included waste oils, rags, paper, cardboard, plastics, degreasers, wood, rubber, and drummed organic solvents. These materials were periodically burned in the pit, usually on a monthly basis. The volume of waste disposed of at BRP6G was not recorded. The materials burned in the burning/rubble pit included potentially hazardous substances, such as organic solvents. In 1955 after disposal activities ceased, the area was covered with soil. Due to the potential that hazardous substances, which if present, could have migrated into the surrounding soil and/or groundwater, BRP6G was designated as a Solid Waste Management Unit (SWMU) subject to the RCRA/ CERCLA process.

The BRP6G is located to the south and is immediately adjacent to the construction laydown area. In addition, the BRP6G is located approximately 300 feet southeast of the Ford Building Seepage Basin and is also located southeast and downgradient of the Ford Building Waste Site. The Federal Facility Agreement (FFA) field start for the RFI/RI for the Ford Seepage Basin is scheduled for 10/20/97. A timecritical removal action for Cesium-137 began on $12 / 18 / 96$ for the Ford Building Waste Site.

\section{Compliance History}

At SRS, waste materials regulated under the Resource Conservation \& Recovery Act (RCRA) are managed in accordance with the requirements of RCRA: Certain SRS activities have required treatment, storage, disposal or post-closure permits under RCRA. Non-regulated units, called solid waste management units (SWMU), include any activity where hazardous constituents may remain 
Figure 1 Location of BRP6G at the Savannah River Site

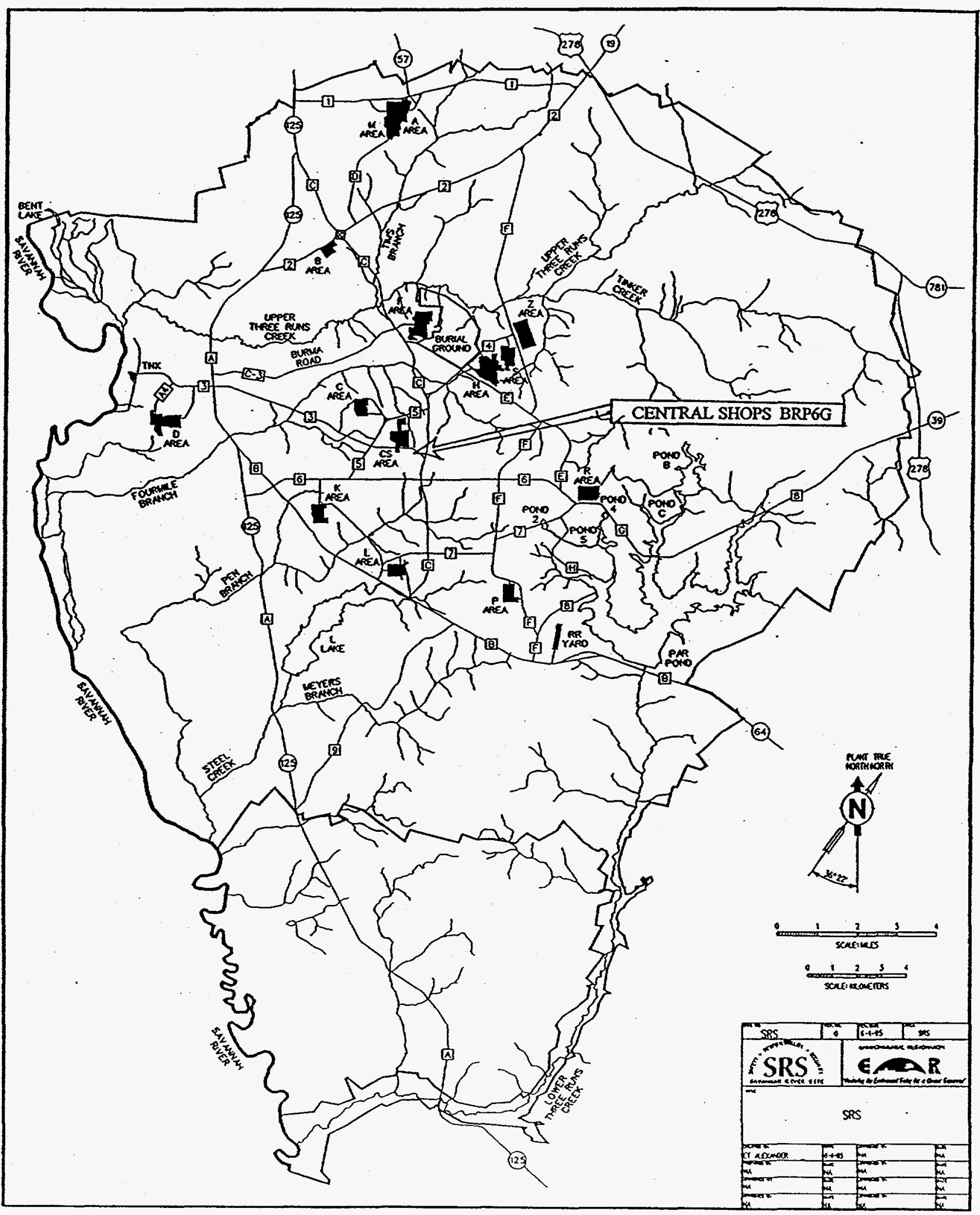


Figure 2 Location of BRP6G in the Central Shops Area of SRS

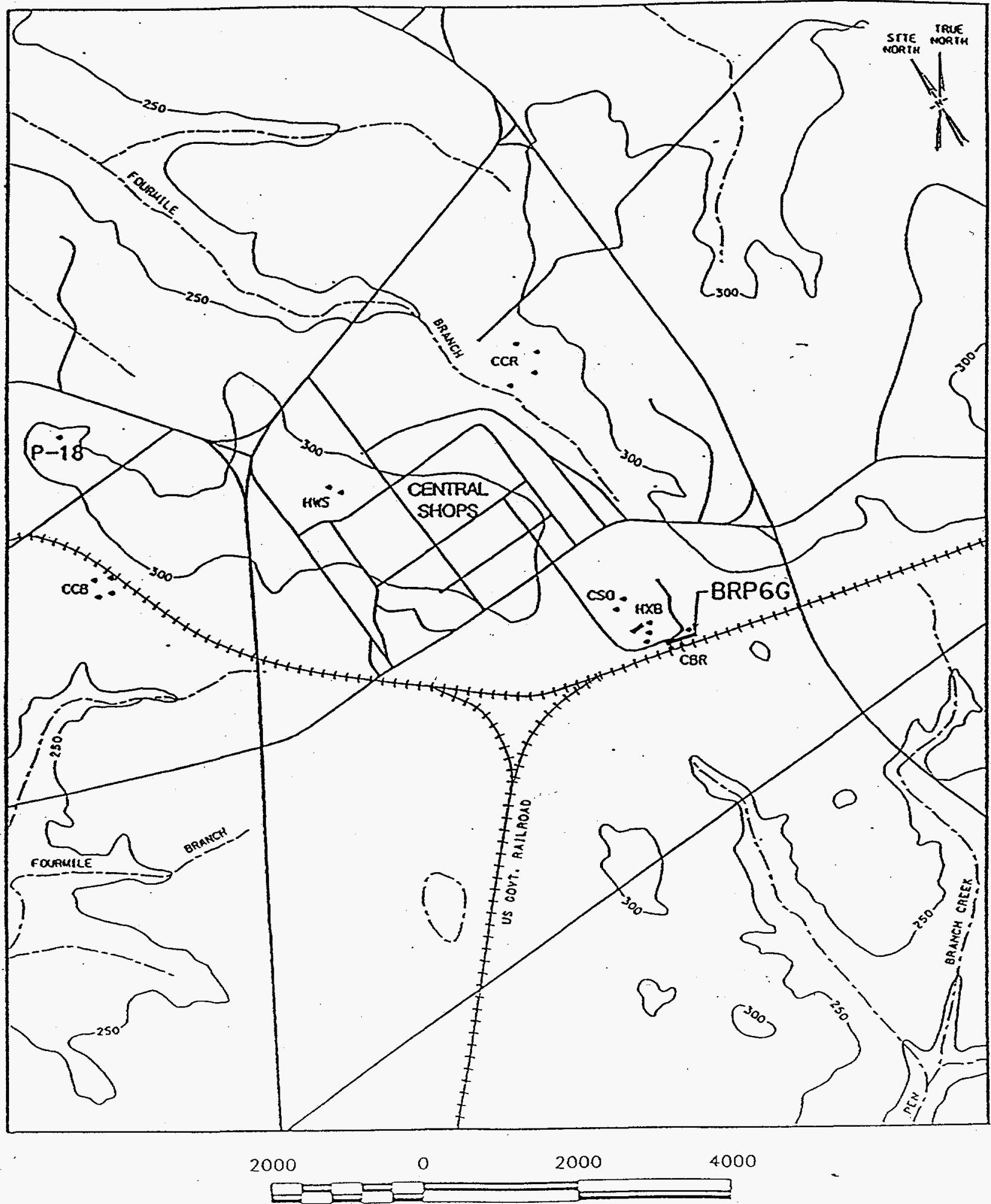

- = Water Table Wells

SCALE IN FEET 
uncontrolled and may potentially release to the environment. Investigation and potential corrective action for these SWMU(s) are mandated under RCRA 3004(u). On September 5, 1995, SRS , received a hazardous waste permit from the South Carolina Department of Health and Environmental Control (SCDHEC) which includes corrective action requirements. Specifically, part $V$ of the permit mandates that SRS establish and implement a RCRA Facility Investigation (RFI) Program to fulfill the requirements specified in Section 3004(u) of RCRA.

Hazardous substance, as defined by CERCLA, are also present in the environment at the SRS. On December 21, 1989, SRS was included on the National Priorities List. This inclusion created a need to integrate the established RFI Program with CERCLA requirements to provide for a focused environmental program. In accordance with Section 120 of CERCLA, DOE has negotiated a Federal Facility Agreement (FFA, 1993) with U. S. Environmental Protection Agency (EPA) and SCDHEC to coordinate remedial activities at SRS into one comprehensive strategy which fulfills these dual regulatory requirements.

The remedial investigation for the Central Shops Burning/Rubble Pit (631-6G) (BRP6G)was completed in 1995. The results of the investigation indicate that there is no impact (or potential impact) to human health or the environment from the BRP6G. Therefore, no action is warranted. No other alternatives were considered.

According to EPA guidance, if there is no current or potential threat to human health and the environment and no action is warranted, the CERCLA 121 requirements are not triggered. This means that these is no need to evaluate other alternatives or the no action alternative against the nine criteria specified under CERCLA.

The remedy selected satisfies both the CERCLA and RCRA 3004(u) requirements. The SCDHEC has modified the SRS RCRA permit to incorporate the selected remedy.

\section{HIGHLIGHTS OF COMMUNITY PARTICIPATION}

Both RCRA and CERCLA require that the public be given an opportunity to review and comment on the draft permit modification and proposed remedial alternative. Public participation requirements are listed in South Carolina Hazardous Waste Management Regulation (SCHWMR) R.61-79.124 and Sections 113 and 117 of CERCLA. These requirements include establishment of an Administrative Record File that documents the investigation and selection of the remedial alternatives for addressing the BRP6G soils and groundwater. The Administrative Record File must be established at or near the facility at issue. The SRS Public Involvement Plan (DOE, 1994) is designed to facilitate public involvement in the decision-making process for permitting, closure, and the selection of remedial alternatives. The SRS Public Involvement Plan addresses the requirements of RCRA, CERCLA, and the National Environmental Policy Act. SCHWMR R.61-79.124 and Section 117(a) of CERCLA, as amended, required the advertisement of the draft permit modification and notice of any proposed remedial action and provided the public an opportunity to participate in the selection of the remedial action. The Statement of Basis/Proposed Plan for the Central Shops Burning/Rubble Pit 631-6G) (WSRC, 1996b), which is part of the Administrative Record File, highlights key aspects of the investigation and identifies the preferred action for addressing the BRP6G.

The FFA Administrative Record File, which contains the information pertaining to the selection of the response action, is available at the EPA office and at the following locations:
U. S. Department of Energy
Public Reading Room
Gregg-Graniteville Library
University of South Carolina-Aiken
171 University Parkway
Aiken, South Carolina 29801
(803) 641-3465 
Thomas Cooper Library

Government Documents Department

University of South Carolina

Columbia, South Carolina 29208

(803) 777-4866

Reese Library

Augusta State University

2500 Walton Way

Augusta, Georgia 30910

(706) 737-1744

Asa H. Gordon Library

Savannah State University

Tompkins Road

Savannah, Georgia 31404

(912) 356-2183

The public was notified of the public comment period through mailings of the SRS Environmental Bulletin, a newsletter sent to approximately 3500 citizens in South Carolina and Georgia, through notices in the Aiken Standard, the Allendale Citizen Leader, the Augusta Chronicle, the Barnwell People-Sentinel, and The State newspapers. The public comment period was also announced on local radio stations.

The 45-day public comment period began on December 10, 1996 and ended on January 23, 1997. A Responsiveness Summary was prepared to address comments received during the public comment period. The Responsiveness Summary is provided in Appendix A of this Record of Decision. The public comment period for the RCRA Permit Modification began on January 27, 1997 and ended on March 12, 1997.

\section{SCOPE AND ROLE OF OPERABLE UNIT WITHIN THE SITE STRATEGY}

The overall strategy for addressing the BRP6G was to: (1) characterize the waste unit delineating the nature and extent of contamination and identifying the media of concern (perform the RFI/RI); (2) perform a baseline risk assessment to evaluate media of concern, constituents of concern (COCs), exposure pathways, and characterize potential risks; and (3) evaluate and perform a final action to remediate, as needed, the identified media of concern.

The BRP6G is a source control and groundwater operable unit which is included in the Pen Branch watershed. Drainage from the Pen Branch water shed area which includes the BRP6G eventually flows to Pen Branch. The Pen Branch watershed area which includes the BRP6G is approximately 15 square miles $(9,600$ acres). The BRP6G covers 0.75 acres or 0.008 percent of the water shed.

No remedial action, which is the preferred remedy, is a final action.

\section{SUMMARY OF OPERABLE UNIT CHARACTERISTICS}

Media Assessment

The Data Summary Report (WSRC, 1995) and RFI/RI/BRA (WSRC, 1996a) contain detailed analytical data for all of the environmental media samples taken in the characterization of BRP6G. These documents are available in the Administrative Record File.

The soils were sampled in two investigations. In the first investigation (March - April 1994), ten soil borings were made. A minimum of four samples were collected from each borehole. Samples included surface soil samples, subsurface soil samples, and deep soil samples down to the water table. The second investigation (November 2 - December 30, 1994) included 12 soil borings, the collection of six surface samples, collection of five surface water/sediment samples, and the installation of three temporary groundwater monitoring wells:

The 17 onsite borings were labeled CS6G 1-9, 11 17 , and 22 . The five background borings were labeled CS6G 10, 18, 19, 20, and 21 (See Figure 4).

Samples from three permanent groundwater monitoring wells were also in this study. The wells used were designated as follows: CBR1 (upgradient); CBR2, 3, 4, and 6 
Figure 3

Potentiometric Surface of the Water Table (Aquifer Unit IB) at the BRP6G

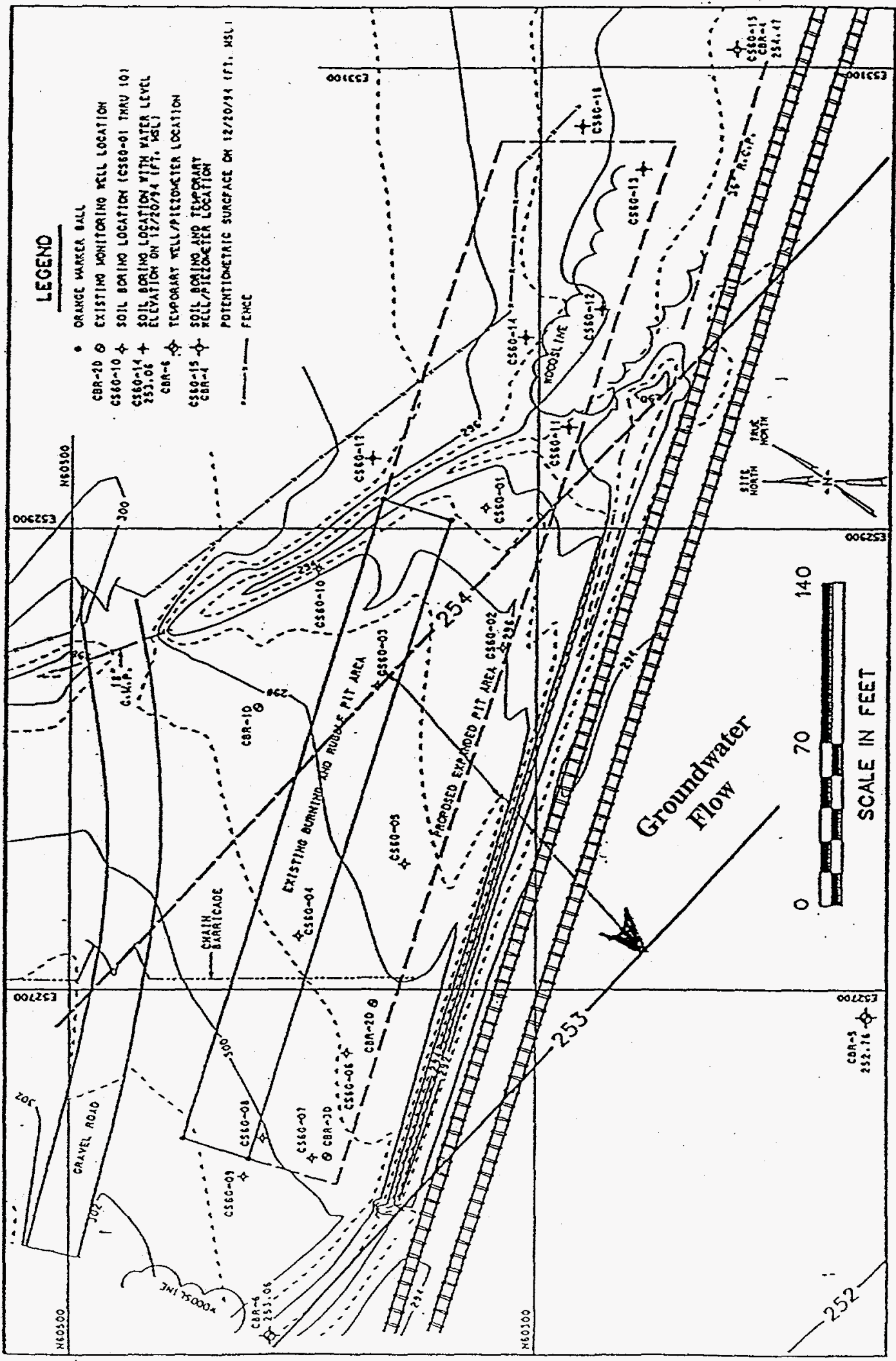



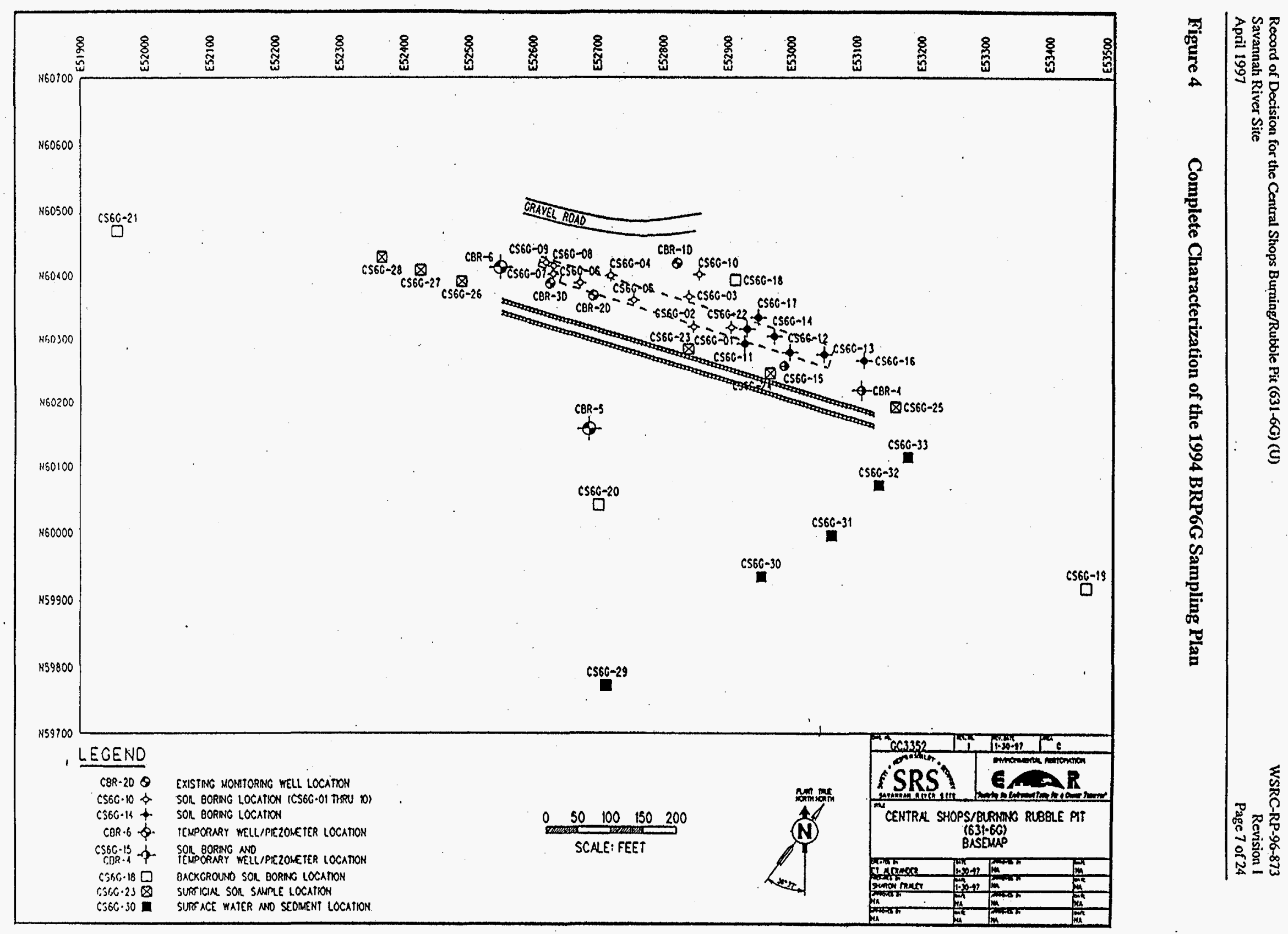
(sidegradient/downgradient); and CBR5 (downgradient) (see Figure 3). The results of the investigation are discussed in the following sections.

\section{Soils}

A total of 74 soil samples were collected and analyzed. Low levels of metal, semi-volatile, volatile, pesticide, polychlorinated biphenyl (PCB), dioxin/furan, and radionuclide indicators were detected in the soil samples from soil borings in this unit. The constituents were detected in greatest concentrations in samples located at the bottom of the pit in the soils, as expected based on the conceptual model.

The following three sections provide a summary of the nature and extent of constituents exceeding background and focuses on those constituents that exceed risk assessment and leachability screening criteria.

\section{Surface Soil (0-2 feet) Summary}

Constituents that were detected above the two times average background concentration include 21 metals, 16 semi-volatiles, 13 volatiles, 4 pesticides, PCB-1254, octachlorodibenzo-p-dioxin (OCDD), and radionuclide indicators (three locations). The locations where the exceedances of background accurred are fairly evenly distributed between borings located inside and outside of the pit. Of all of the constituents found above background, seven were designated as contaminants of potential concern (COPCs) in the baseline risk assessment, which are presented in Table 1. With the exception of OCDD, which was found only in the eastern third of the unit, the other constituents were randomly distributed across the unit. PCB-1254 was detected only once in soil boring location CS6G-12. Octachlorodibenzo-p-dioxin was detected at three locations outside of the pit and one inside the pit.

Risks that were determined for surface soils constituents of potential concern can be found in Section VI.

\section{Shallow Subsurface Soil (0-5 feet) Summary}

Constituents that were above the two times average background concentration are essentially the same as in the surface soils, which is consistent with the conceptual site model given that this zone is predominantly fill material. Eight of the constituents found above two times the average background concentration were designated as COPCs, which is presented in Table 2. Beryllium, the additional COPC not included in the $0-2$ foot interval, is also randomly distributed across the unit.

These COPCs were evaluated for their potential contribution to risk in Section IV. The 0-5 foot soil interval is evaluated for a possible future excavation scenario - which-could bring these constituents to the surface where they could come into contact with humans or the environment

\section{Leachability From Soils}

One of the concerns regarding the site specific contaminants (SSCs) that have been identified in the vadose zone is whether the potential exists for these contaminants to migrate to the water table in a sufficient quantity over time such that future groundwater concentrations could create a risk (i.e. exceed MCLs or other risk based criteria). The SSCs are contaminants found in the vadose zone from 0 feet to the water table. Contaminants were identified as SSCs based upon their frequency of detection above two times the average background and their health risks and/or mobility. The SSCs include seven inorganic constituents, nine semi-volatiles, six volatiles, two pesticides and OCDD. The average soil concentration of the SSCs were compared to generic EPA soil screening levels (SSLs). Those failing generic SSLs were further compared to site specific soil screening levels. Only barium, chromium, benzo(a)pyrene, benzo(b)-fluoranthene, and dieldrin possessed an average concentration which was above the site specific SSL value. This screening process is demonstrated in Table 3. 
Table 1 Analytes and COPCs in Surface Soil (0-2 ft) Used in Calculations of Risk \& Hazard

\begin{tabular}{|c|c|c|c|c|c|c|c|c|}
\hline Analyte & Unit & $\begin{array}{c}\text { Number } \\
\text { of } \\
\text { Detects }\end{array}$ & $\begin{array}{c}\text { Total } \\
\text { Number } \\
\text { of Samples }\end{array}$ & $\begin{array}{c}\text { Detection } \\
\text { Limit Range } \\
\text { for Undetects }\end{array}$ & $\begin{array}{l}\text { Maximum } \\
\text { Detected } \\
\text { Concentration }\end{array}$ & UL 95 & $\begin{array}{c}\text { Exposure } \\
\text { Concentration } \\
\text { (a) }\end{array}$ & $\begin{array}{l}\text { Average } \\
\text { Concentration } \\
\text { (Background) }\end{array}$ \\
\hline $\begin{array}{l}\text { 2-Hexanone } \\
\text { Anthracene } \\
\text { Arsenic } \\
\text { Benz̧o }(g, h, t) \text { perylene } \\
\text { Iron } \\
\text { OCDD } \\
\text { PCB-1254 }\end{array}$ & $\begin{array}{l}\mathrm{mg} / \mathrm{kg} \\
\mathrm{mg} / \mathrm{kg} \\
\mathrm{mg} / \mathrm{kg} \\
\mathrm{mg} / \mathrm{kg} \\
\mathrm{mg} / \mathrm{kg} \\
\mathrm{mg} / \mathrm{kg} \\
\mathrm{mg} / \mathrm{kg}\end{array}$ & $\begin{array}{c}1 \\
1 \\
4 \\
1 \\
25 \\
8 \\
2\end{array}$ & $\begin{array}{l}7 \\
25 \\
25 \\
25 \\
25 \\
25 \\
25\end{array}$ & $\begin{array}{c}0.1-0.12 \\
0.21-0.25 \\
0.74-0.9 \\
0.21-0.25 \\
\text { No undetects } \\
0.05 \\
10.6-12\end{array}$ & $\begin{array}{c}0.00038 \\
0.0146 \\
7.92 \\
0.0219 \\
31400 \\
0.00759 \\
0.115\end{array}$ & $\begin{array}{c}0.000228 \\
0.000554 \\
1.97 \\
0.000643 \\
14302.98 \\
0.001358 \\
0.02302\end{array}$ & $\begin{array}{c}0.000228 \\
0.000554 \\
1.97 \\
0.000643 \\
14302.98 \\
0.001358 \\
0.023023\end{array}$ & $\begin{array}{c}\text { Not Detected } \\
\text { Not Detected } \\
\text { Not Detected } \\
\text { Not Detected } \\
13487.78 \\
0.00033 \\
\text { Not Detected }\end{array}$ \\
\hline
\end{tabular}

(a) Exposure concentration is the lesser of the maximum detected and the UL 95.

Table 2 Analytes and COPCs in Shallow Subsurface Soil (0-5 ft) Used in Calculations of Risk \& Hazard

\begin{tabular}{|c|c|c|c|c|c|c|c|c|}
\hline Analyte & Unit & $\begin{array}{c}\text { Number } \\
\text { of } \\
\text { Detects }\end{array}$ & $\begin{array}{c}\text { Total } \\
\text { Number } \\
\text { of Samples }\end{array}$ & $\begin{array}{l}\text { Detection } \\
\text { Limit Range } \\
\text { for Undetects }\end{array}$ & $\begin{array}{l}\text { Maximum } \\
\text { Detected } \\
\text { Concentration }\end{array}$ & UL 95 & $\begin{array}{c}\text { Exposure } \\
\text { Concentration } \\
\text { (a) }\end{array}$ & $\begin{array}{c}\text { Average } \\
\text { Concentration } \\
\text { (Background) }\end{array}$ \\
\hline 2-Hexanone & $\mathrm{mg} / \mathrm{kg}$ & 1 & 9 & $0.1-0.12$ & 0,00038 & 0.000194 & 0.000194 & Not Detected \\
\hline Anthracene & $\mathrm{mg} / \mathrm{kg}$ & $\mathbf{1}$ & 37 & $0.21-0.33$ & 0.0146 & 0.000405 & 0.000405 & Not Detected \\
\hline Arsenic & $\mathrm{mg} / \mathrm{kg}$ & $\boldsymbol{T}$ & 37 & $0.74-1.24$ & 9.22 & 2.379 & 2.379 & 1.15 \\
\hline Benzo $(g, h, i)$ perylene & mg/kg & $\mathbf{I}$ & 37 & $0.21-0.33$ & 0.0219 & 0.000445 & 0.000445 & Not Detected \\
\hline Beryltium & mo/kg & .37 & 37 & No detects & 0.37 & 0.161 & 0.161 & 0.15 \\
\hline Iron & $\mathbf{m g} / \mathbf{k g}$ & 37 & 37 & No defects & 49300 & 20218.560 & 20218.56 & 17127.86 \\
\hline OCDD & $\mathrm{mg} / \mathrm{kg}$ & 14 & 37 & $0.05-0.07$ & 0.0194 & 0.004 & 0.004064 & 0.00096 \\
\hline PCB-1254 & $\mathbf{m g} / \mathbf{k g}$ & 2 & 37 & $10.6-16.6$ & 0.115 & 0.01925 & 0.019254 & Not Detected \\
\hline
\end{tabular}

(a) Exposure concentration is the lesser of the maximum detected and the UL 95. 
Table 3 Average Soil Concentrations of SSCs and COPCs Compared to Soil Screening Levels
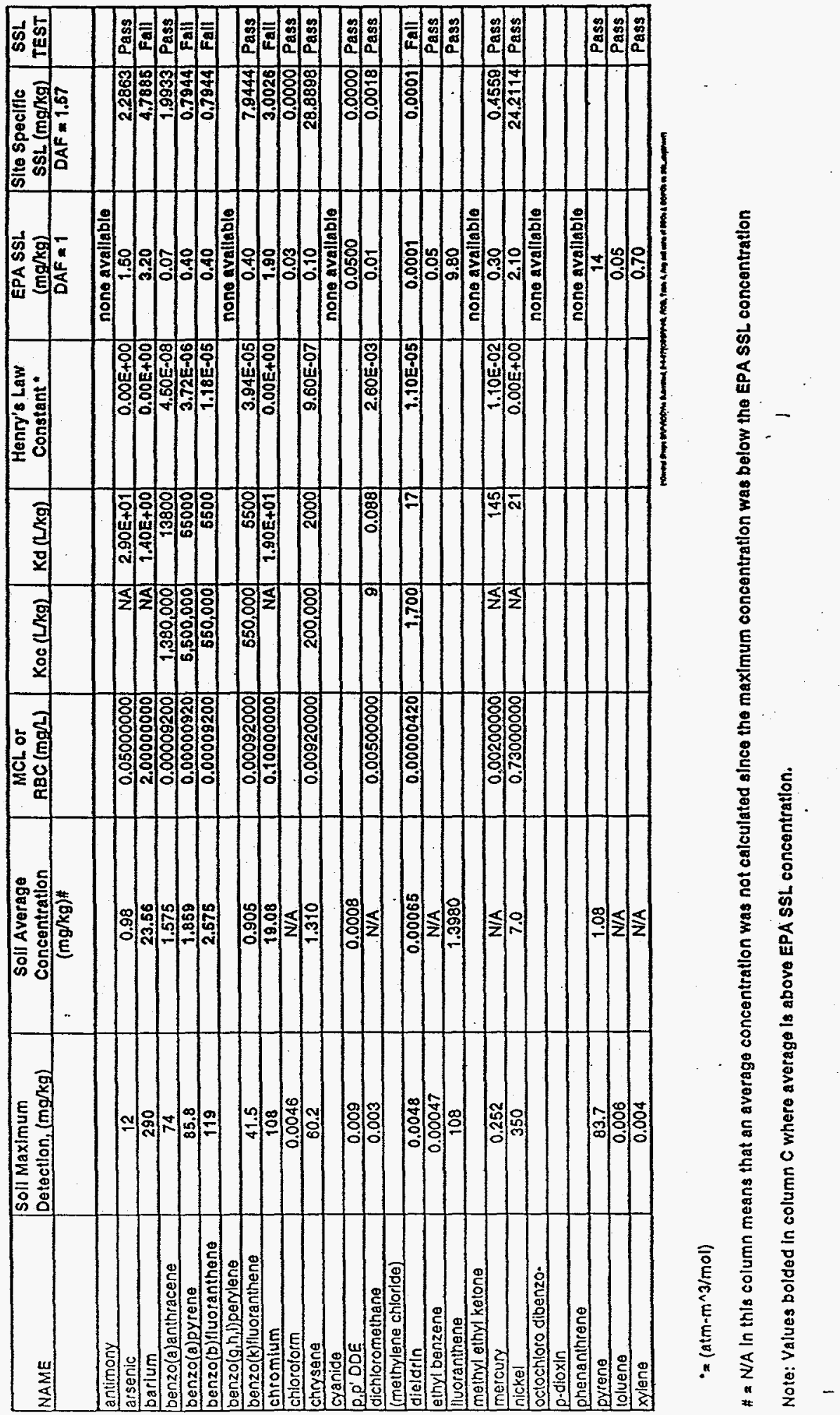
The two contaminants, benzo(a)pyrene and benzo(b)fluoranthene, had exceedingly high average concentrations due mainly to the two samples from borings in the pit. These samples CS6G 1404 (4-6 ft.) and CS6G 0902 (3.56-5.6 ft.) had inordinately high concentrations of all of the polycyclic aromatic hydrocarbons because of their position in the pit, that is, the samples were taken directly at the position of the burned material at the base of the pit. The samples taken two feet below these samples exhibited concentrations in the range of ten to one hundred times lower than the previous samples, and were considerably lower than the EPA SSL values. The inherent insolubility of polycyclic aromatic hydrocarbons and the soil cover of this burning/rubble pit has apparently served to inhibit the movement of these substances toward the groundwater, as the highest concentrations are located where they were forty years ago when the pit was covered.

Dieldrin was also noted as having an average concentration above the site specific SSL. This contaminant was only detected in five out of seventy-four samples. Three of the samples are above the SSL, with an average of $0.0022 \mathrm{mg} / \mathrm{kg}$. The average concentration of dieldrin was based on only five detections out of seventy-four samples analyzed which is very conservative. If all the samples were taken into consideration for determining the average, the average would be considerably less. Thus based on the conservative assumptions used in the model and the empirical data, dieldrin is not expected to impact groundwater in the future. Dieldrin was only detected in the top four feet of the samples analyzed.

The RCRA Facility Investigation/Remedial Investigation/Baseline Risk Assessment performed an analysis that indicates that dieldrin could migrate to the groundwater and would reach the groundwater in 28.1 years with a concentration of $0.00219 \mathrm{mg} / \mathrm{L}$. The risk at this concentration is calculated to be $7.89 \times 10^{-6}$, which is above the $10^{-6}$ threshold. The length of time that the site has been undisturbed is in excess of the 28.1 years, and dieldrin has not migrated to detectable quantities below the four foot level in soils and has not been detected in groundwater. Further, the limited soil data that is available delineates a clayey soil which would also inhibit migration.

Barium was detected in the soil with an average concentration of $23.56 \mathrm{mg} / \mathrm{kg}$. Modeling predicted that measurable levels of barium would reach the groundwater, however, the hazard index calculation showed that barium poses no undue risk to future residents or future industrial workers.

Groundwater modeling also predicted that chromium would migrate to the groundwater in measurable levels. Chromium +3 , the dominant oxidation state for this environment, poses a minimal risk with a hazard index of 0.004 for the future resident from ingestion of groundwater peaking at a time in excess of 570 years in the future. Although not considered to be present, chromium in the +6 state would pose a risk with a hazard index of 2 for the future resident from ingestion of groundwater. The time to peak groundwater concentration is in excess of 570 years in the future. For these reasons, chromium will not have an unacceptable impact on future groundwater quality.

Barium, chromium, benzo(a)pyrene, benzo(b)fluoranthene, and dieldrin exhibit average soil detection concentrations which exceed site specific SSLs. Based on the previous discussions regarding the behavior of the specific BRP6G SSCs in the environment, groundwater modeling results, and the results of the comparison to site specific SSLs, the contaminants present in the soils at the BRP6G have little likelihood of impacting future groundwater quality. This is due mainly to the nature of the locations of the highest contaminants concentrations being in the charred material in the case of the polycyclic aromatic hydrocarbons (PAHs), minimal increases in the hazard indices for future residents from ingestion of groundwater predicted from groundwater modeling for barium and chromium which peak at over 570 years from the present, and detections only in the upper four feet of soil in the case of the dieldrin. 


\section{Sediment/Surface Water}

There are no surface water impoundments in the vicinity of BRP6G. Drainage water samples were collected in the downgradient ditch at five locations. The source of the drainage water is not entirely from BRP6G. Upgradient surface water runoff originates from a large construction materials lay-down yard and the Ford Building area. Both upgradient and downgradient surface water samples indicated the presence of metals, semi-volatile organics, volatile organics, and radionuclides.

Both upgradient and downgradient sediment samples indicated the presence of various metals, small amounts of volatiles organics, semi-volatile organics, gross alpha radionuclides, and OCDD.

Because of the uncertainty of the origin of the analytes detected in the surface water and sediment, the data collected cannot be utilized to effectively characterize the BRP6G site. Regardless of their origin, the levels of contaminants detected would pose insignificant human health risk based on typical exposure assumptions. The potential environmental impact of these contaminants will be addressed on a larger scale in the Pen Branch watershed assessment.

\section{Groundwater}

A total of 27 groundwater samples were collected. Compounds that were intermittently detected more than once in wells downgradient from the pits include: aluminum, bis(2-ethylhexyl)phthalate (B2EHP), bromo-dichloromethane, chloroform, and dibromo-chloromethane.

The following is a list of groundwater contaminants of potential concern (COPCs) with their maximum detected levels for all constituents and the criteria that they exceed, and the Standard Value.

\begin{tabular}{lccc} 
COPC & $\begin{array}{c}\text { Maximum } \\
\text { Value }(\mu \mathrm{g} / \mathrm{L})\end{array}$ & $\begin{array}{c}\text { Criteria } \\
\text { Exceeded }\end{array}$ & $\begin{array}{c}\text { Standard } \\
(\mu \mathrm{g} / \mathrm{L})\end{array}$ \\
\hline Aluminum & 41,400 & 4 & 50 \\
Arsenic & 5.1 & 1,2 & 50 \\
Beryllium & 0.409 & 1 & 4 \\
Iron & 94,900 & 2,4 & 300 \\
Lead & 89.1 & 3,5 & 15,50 \\
Manganese & 297 & 4 & 50 \\
B2EHP & 6.11 & $1,2,3$ & 6
\end{tabular}

1) caused risk in excess of $1 \times 10^{-6}$

2) caused Hazard Index (HI) values to exceed

3) exceeded MCLs (federal or State)

4) exceeded the Secondary Drinking Water Standards

5) exceeded EPA at-the-tap action level.

Lead was detected at a concentration above the EPA at-the-tap action level $(\overline{15} \mu \mathrm{g} / \mathrm{L})$ and the South Carolina groundwater protection standard $(50 \mu \mathrm{g} / \mathrm{L})$ in well CBR4 with a detection of 89.1 $\mu g / L$. This sample was collected with a bailer and was very turbid. Turbid samples tend to have much higher levels of metals present than clear samples. For this reason, this level of lead is suspect and may not represent the actual conditions in the groundwater. A subsequent sample taken from the same well 25 days later showed a level of only $11.8 \mu \mathrm{g} / \mathrm{L}$ which is below both the EPA and the South Carolina standards.

Bis(2-ethylhexyl)phthalate, a semi-volatile, exceeded the Primary Drinking Water Standard concentration of $6.0 \mu \mathrm{g} / \mathrm{L}$ in the same sample with a value of $6.11 \mu \mathrm{g} / \mathrm{L}$. Subsequent sampling in the same well 25 days later showed bis(2ethylhexyl)phthalate at $0.254 \mu \mathrm{g} / \mathrm{L}$.

All of the constituents (arsenic, beryllium, lead, and bis(2-ethylhexyl)phthalate) providing risk or detections above MCLs were obtained from monitoring well CBR4. None of these constituents was consistently detected above their associated MCLS. Well CBR4 is located west of the unit in a hydrologically side to up gradient position. It would be unlikely that any constituents detected in this well could be from this unit. The most likely source, if constituents were consistently detected in this well, would be upgradient of this unit. It should be noted that these constituents were not detected above MCLs in the downgradient well 
(CBRS). This data, in conjunction with the frequency and occurrence of detections, suggest that there is little or no impact from the unit to the groundwater.

The Secondary Drinking Water Standards are primarily for esthetic purposes and are not enforceable standards for groundwater.

The uncertainty associated with the groundwater results is discussed further in the Uncertainty section.

\section{SUMMARY OF OPERABLE UNIT RISKS}

As a component of the remedial investigation process, a baseline risk assessment was prepared for the BRP6G. The baseline risk assessment consists of human health and ecological risk assessments. Summary information for the human health and ecological risk assessments follows.

\section{Human Health Risk Assessment}

As part of the investigation/assessment process for BRP6G, a BRA was performed using data generated during the assessment phase. The BRA is described in the RFI/RI/BRA report (WSRC, 1996a).

The BRA designates the COPCs based on a conservative screen against background concentrations, and the relative potential of the chemicals to cause toxic or carcinogenic effects.

An exposure assessment was performed to provide: an indication of the potential exposures which could occur based on the chemical concentrations detected during sampling activities. The only current exposure scenario identified for BRP6G was for on-site visitors. Conservative future exposure scenarios identified for BRP6G included future industrial workers and future resident adults and children. The reasonable maximum exposure (RME) concentration value was used as the exposure point concentration.
Carcinogenic risks are estimated as the incremental probability of an individual developing cancer over a lifetime as a result of pathway-specific exposure to cancer-causing contaminants. The risk to an individual resulting from exposure to non-radioactive chemical carcinogens is expressed as the increased probability of cancer occurring over the course of a 70 year lifetime. Cancer risks are related to the EPA target risk range of one in ten thousand ( $1 \times$ $10^{-4}$ ) to one in one million $\left(1 \times 10^{-6}\right)$ for incremental cancer risk at NPL sites. Risk levels in the $1 \times 10^{-4}$ to $1 \times 10^{-6}$ range require a risk management decision where specific actions to reduce risk may be considered while cancer risk levels below $1 \times 10^{-6}$ are considered to be insignificant.

Non-carcinogenic effects are also evaluated to identify a level at which there may be concern for potential non-carcinogenic health effects. The hazard quotient, which is the ratio of the exposure dose to the reference dose (RID), is calculated for each contaminant. Hazard quotients are summed for each exposure pathway to determine the specific hazard index (HI) for each exposure scenario. If the $\mathrm{HI}$ exceeds unity $(1.0)$, the potential exists that adverse health effects might occur.

\section{Current Land Use - Noncarcinogenic Hazards}

The BRA shows that potential adverse noncarcinogenic health effects are not likely to occur, because none of the HIs exceeded a value of one.

\section{Current Land Use - Carcinogenic Risks}

Under the current land use scenario, human health risks were calculated for both the current material yard worker and the current groundwater sampler. The only pathway that exceeded $1 \times 10^{-6}$ was inhalation of groundwater which was $2 \times 10^{-6}$ from chloroform. The risk for inhalation from groundwater was calculated using very conservative methods which assumed that all of the chloroform in the water vaporized and was inhaled during the groundwater sampling. Thus 
the total risks to current workers are considered to be insignificant. Figure 5 summarizes these calculations.

Future Industrial Land Use - Noncarcinogenic Hazards

The only $\mathrm{HI}$ value for the hypothetical future industrial worker that exceeds 1.0 is for ingestion of groundwater (see Figure 6). The 2.5 value for ingestion of water is driven by iron.

\section{Future Industrial Land Use - Carcinogenic Risks}

For the hypothetical future worker, only the total carcinogenic risk, by pathway, from ingestion of groundwater $\left(1 \times 10^{-5}\right)$ exceeds $1 \times 10^{-6}$ (see Figure 6 ). This risk is driven by arsenic and beryllium. 
Figure 5

Conceptual Site Model for Soil Risks for Current Groundwater Sampler and Current Material Yard Worker
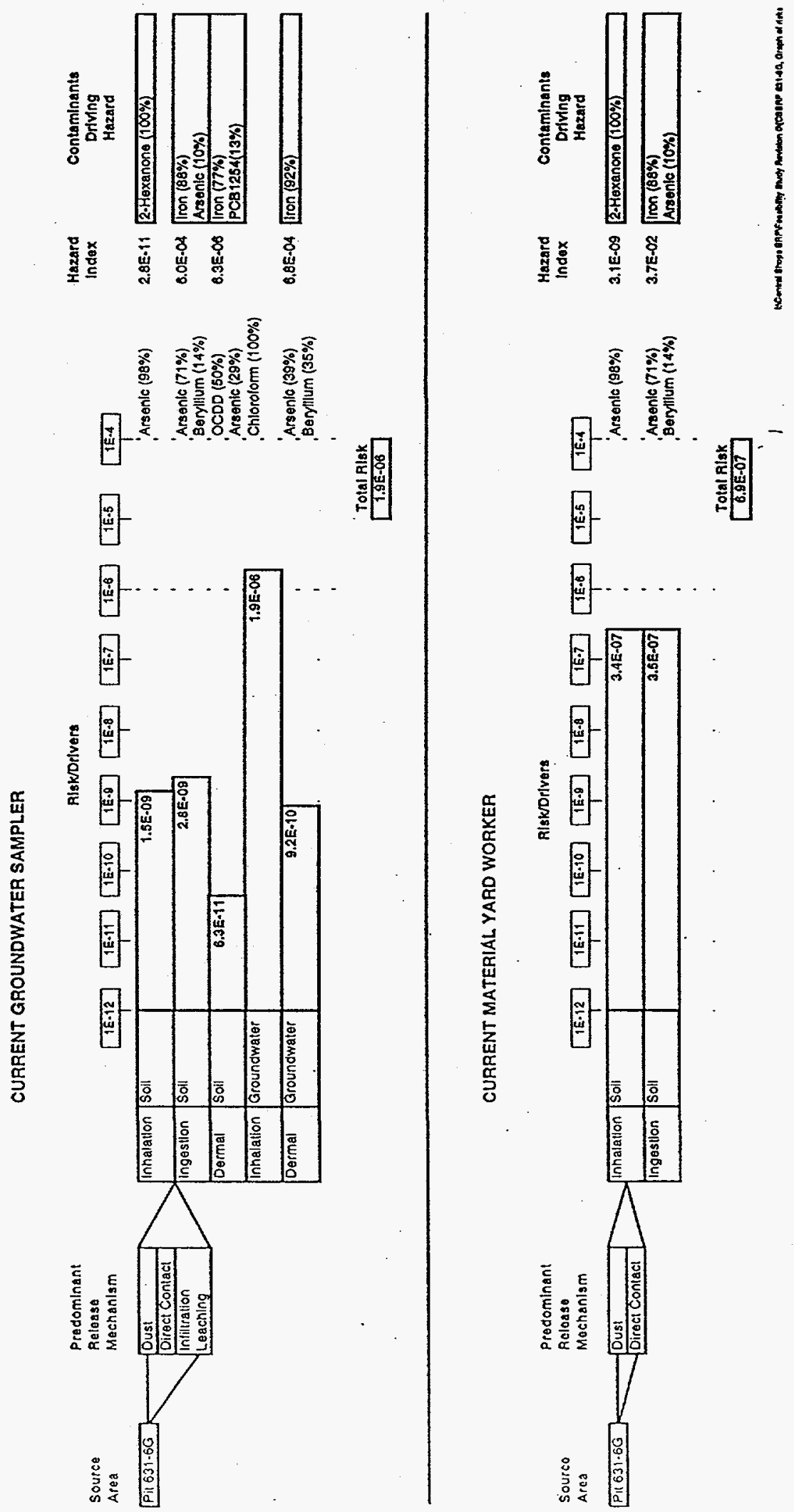
Record of Decision for the Central Shops Buming/Rubble Pit (631-6G) (U)

Savannah River Site

WSRC-RP-96-873

Revision 1

April 1997

Page 16 of 24

Figure 6 Conceptual Site Model for Soil Risks for Hypothetical Future Industrial Workers
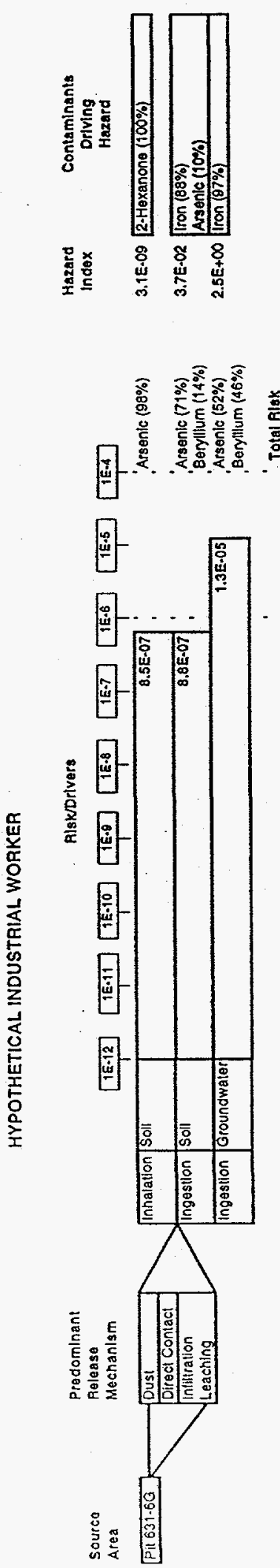
HYPOTHETICAL RESIDENT

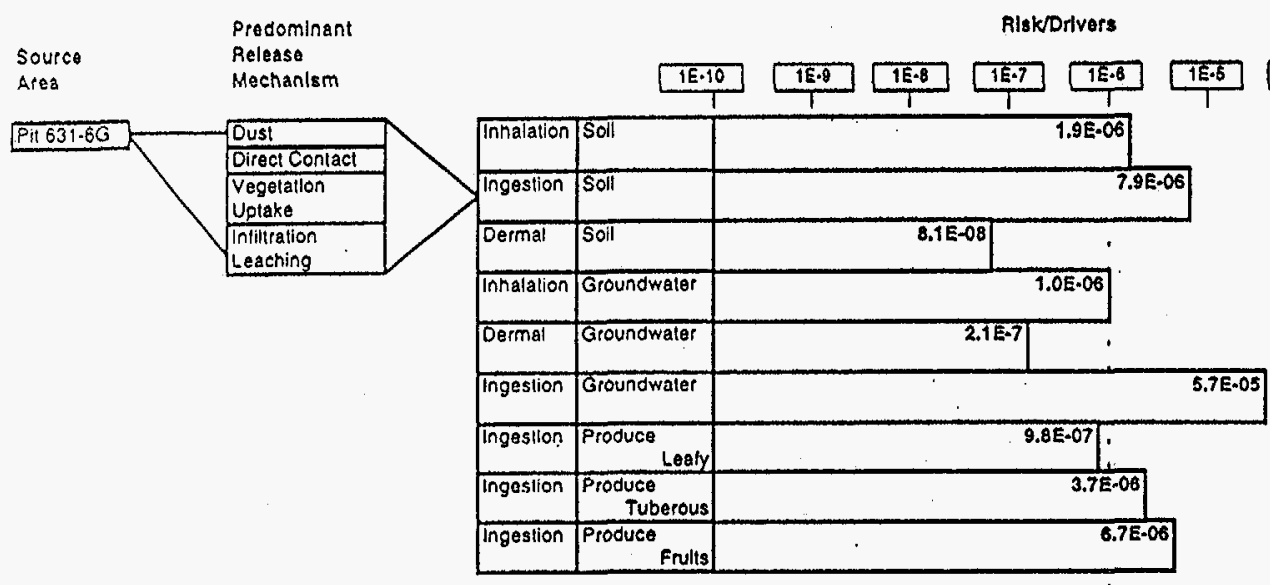

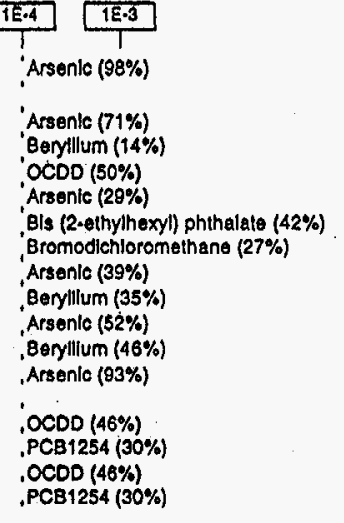

Hazare

Contaminants

Driving

2.18-00 2-Hexanone (10\%)

$1.1 \mathrm{E}+\infty$ 1ron (88\%)

3.2E.03 ron (73\%)

2.2E-02 CCB1254 (13\%)

Els (2-ethylhexy) phithalate (43\%)

$6.1 E .02$ [ron (92\%)

$2.3 E+01$ 1100n (97\%)

2.1E-02 Arsentc (54\%)

$\operatorname{tron}(46 \%)$

7.1E-02 PCB1254 (57\%)

1.3E-01 $\frac{1}{\text { PCB (21254 (5) }}$ Iron (21\%)

\section{Total Rlask}

Source
Area $\begin{aligned} & \text { Predominant } \\ & \text { Retease } \\ & \text { Mechanlsm }\end{aligned}$

ค̣lsk/Drlvers

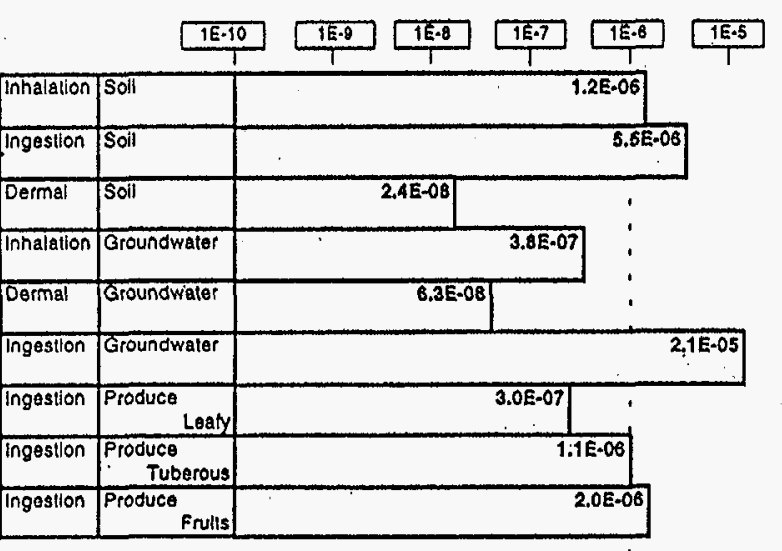

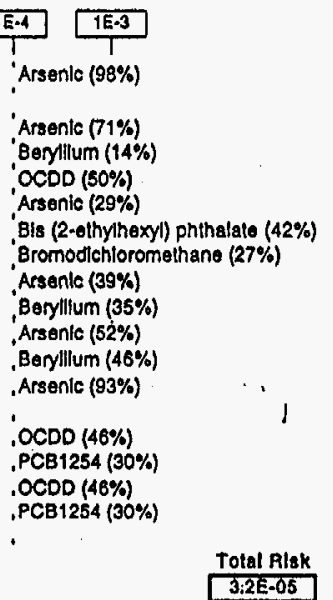

Hazard Contaminants

$$
\text { Mazard }
$$

1.8E-08 2-Hexanone (100\%)

$9.8 E-01$ ron (88X)

2.0E-03 Pron (73\%)

1.6E-02 Chlorolom (47\%)

Bis (2-ethythexy) phithalate (43\%)

$3.9 \mathrm{E}-03$ Iron (92\%)

1.6E+01 1ron (97\%)

1.3E-02 Arsenle (54\%

4.5E-02 Iron (46\%)

\begin{tabular}{l} 
4.5E-02 $\operatorname{PCB} 1254(57 \%)$ \\
\hline $\operatorname{ron}(21 \%)$
\end{tabular}

8.0E-02 $\frac{\text { PCE1254 (57\%) }}{\operatorname{PCon} 121 \%)}$ iron (21\%) 


\section{Future Residential Land Use - Noncarcinogenic Hazards}

Two HIs for hypothetical future resident adults exceeded a value of 1.0 (see Figure 7 ). These were: 1.1 for ingestion of soil, driven by iron and arsenic; and 23 for ingestion of groundwater, driven by iron. One HI exceeded 1.0 for a hypothetical future resident child. This was 16 for ingestion of groundwater, driven by iron (from the bailed sample).

\section{Future Residential Land Use - Carcinogenic Risks}

The total carcinogenic risk for the hypothetical future resident adult is $8 \times 10^{-5}$ (see Figure 7). The following carcinogenic risks equaled or exceeded $1 \times 10^{-6}: 2 \times 10^{-6}$ for inhalation of soil from arsenic, $8 \times 10^{-6}$ from ingestion of soil from arsenic, $1 \times 10^{-6}$ for inhalation of groundwater driven by bis(2-ethylhexyl)phthalate and bromodichloro-methane, $6 \times 10^{-5}$ for ingestion of groundwater due to arsenic and beryllium, $4 \times 10^{-6}$ for ingestion of homegrown tuberous produce due to $\mathrm{OCDD}$ and $\mathrm{PCB}-1254$, and $7 \times 10^{-6}$ for ingestion of homegrown fruit due to OCDD and PCB-1254.

The total carcinogenic risk for the hypothetical future child resident is $3 \times 10^{-5}$. Several carcinogenic risks equaled or exceeded $1 \times 10^{-6}$ : $1 \times 10^{-6}$ for inhalation of soil driven by arsenic; $6 \times 10^{-6}$ for ingestion of soil driven by arsenic and beryllium; $2 \times 10^{-5}$ for ingestion of groundwater driven by arsenic and beryllium, $1 \times 10^{-6}$ from ingestion of homegrown tuberous produce due to OCDD and PCB-1254, and $2 \times 10^{-6}$ from ingestion of homegrown fruit due to OCDD and PCB-1254.

Uncertainty

Risks from arsenic, beryllium, and iron in the pit soil were calculated since a conservative screening method (comparison of site maximum to two times the background mean) indicated that they were elevated above background levels. Background levels of organic compounds (e.g., OCDD) are not considered in the risk assessment, however, the observed concentration ranges for both on-site and background samples are very similar. OCDD was detected in both surface and shallow subsurface background samples. OCDD has been found randomly distributed in SRS background samples. $\dot{A}$ statistical comparison between site samples and background samples for arsenic, beryllium, and OCDD indicated with 90 percent confidence that the site and background samples are part of the same distribution with the exception of arsenic in the $0-5$ foot interval.

The contribution of risk from background concentrations of arsenic and iron are significant when compared to the onsite values. For the $0-5 \mathrm{ft}$ exposure unit, the background RME for arsenic is $2.30 \mathrm{mg} / \mathrm{kg}$, as compared to $2.38 \mathrm{mg} / \mathrm{kg}$ on unit. The background RME for iron is 22,710 , as compared to the on unit value of $20,218 \mathrm{mg} / \mathrm{kg}$.

The main contributors to groundwater risk are arsenic and beryllium. Lead exceeded the EPA atthe-tap guidance while bis(2-ethylhexyl)phthalate exceeded the groundwater MCL. The analytical values used for all four of these constituents came from the December 3, 1994 sampler from well CBR4. This sample was highly turbid. A subsequent sample taken from the same well 25 days later showed reduced values for all of these constituents. If this sample was not included in the risk analysis, arsenic and beryllium would contribute considerably lower risks. Removal of this sample from consideration would also eliminate the only MCL exceedences (lead and bis(2-ethylhexyl)phthalate) found at BRP6G. The values from these sampling events are shown below:

\begin{tabular}{|c|c|c|}
\hline Constituent & $\begin{array}{r}(\mu \mathrm{g} / \mathrm{L}) \\
12 / 3 / 94\end{array}$ & $\begin{array}{c}(\mu \mathrm{g} / \mathrm{L}) \\
12 / 28 / 94\end{array}$ \\
\hline Arsenic & 5.1 & ND \\
\hline Beryllium & 0.739 & 0.409 \\
\hline Lead & 89.1 & 11.8 \\
\hline B2EHP & 6.11 & 0.254 \\
\hline
\end{tabular}

The risk for groundwater ingestion from arsenic is based on one detection in a bailed sample. This risk is highly suspect since only one of 27 groundwater samples detected arsenic and this was 
from a bailed sample. Bailed samples often remove water which contains suspended solids and concentrated levels of contaminants which may not be representative of the actual groundwater. To verify this anomaly, an additional sample was taken from this same well 25 days later. Arsenic was not detected in this sample.

The only detection of beryllium in groundwater in excess of two times background was from the same 12/3/94 turbid sample taken from well CBR4.

The only groundwater detection of lead and bis(2ethylhexyl)phthalate in excess of their respective maximum contaminant levels (MCL) was from the same 12/3/94 turbid, bailed sample from CBR4.

All of the detections for aluminum, manganese, and iron which exceeded the Secondary Drinking Water Standards were also from the turbid samples taken from well CBR4. The levels of iron used to calculate HIs of 23 for future residents and 16 for a future child for ingestion of groundwater attributed were also obtained from the same samples. Elimination of the data from these turbid samples would remove all detections over the Secondary Drinking Water Standards and the HIs for ingestion of groundwater in excess of 1 .

All of the constituents (arsenic, beryllium, lead, and bis(2-ethylhexyl)phthalate) providing risk or detections above MCLs were obtained from monitoring well CBR4. None of these constituents was consistently detected above their associated MCLS. Well CBR4 is located west of the unit in a hydrologically side to up gradient position. It would be unlikely that any constituents detected in this well could be from this unit. The most likely source, if constituents were consistently detected in this well, would be upgradient of this unit. It should be noted that these constituents were not detected above MCLs in the downgradient well (CBR5). This data, in conjunction with the frequency and occurrence of detections, suggest that there is little or no impact from the unit to the groundwater.
Discounting the analysis of this sample would eliminate any MCL exceedences for groundwater associated with BRP6G.

\section{Ecological Risk Assessment}

Based on characterization of the environmental setting at BRP6G and identification of potential receptor organisms (plants and animals), a conceptual site model was developed to determine how plants and animals could be exposed to COPCs.

Evaluation of the concentrations of lead, copper, $\mathrm{PCB}$, and cadmium along with their toxicity, and the limited habitat provided by BRP6G result in a determination that ecological risk is insignificant.

\section{Site-Specific Considerations}

Site-specific considerations, based on the conclusions of the BRA and RFI/RI, which suggest limited or no potential for significant risk include:

1) BRP6G contains a large volume of buried nonhazardous waste material and cover soil.

2) The levels of surface soil contamination recognized during characterization are generally very low. The contaminants in the trench bottom soils are very stable chemically and exhibit limited mobility in the soil as indicated by the deep soil sampling results.

3) The groundwater monitoring program indicates that there has not been significant impact from the waste materials in the pits.

\section{Remedial Action Objectives}

Remedial action objectives specify unit-specific contaminants, media of concern, potential exposure pathways, and remediation goals. Remediation goals are developed based upon ARARs or can be risk-based.

ARARs are those cleanup standards, standards of control, and other substantive requirements, criteria, or limitations promulgated under federal, state, or local environmental law that specifically 
address a hazardous substance, pollutant, contaminant, remedial action, location, or other circumstance at a CERCLA site. Other available information that is not an ARAR (e.g., advisories, criteria, guidance) may be considered in the analysis if it helps to ensure protectiveness or is otherwise appropriate for use in a specific alternative. These guidances are referred to as tobe-considered (TBC) guidances. Three types of ARARs; action-, chemical-, and location-specific; have been developed to simplify identification and compliance with environmental requirements. Action-specific requirements set controls on the design, performance and other aspects of implementation of specific remedial activities. Chemical-specific requirements are mediaspecific, health-based concentration limits developed for site-specific levels of contaminants in specific media. Location-specific ARARs must consider federal, state, and local requirements that reflect the physiographical and environmental characteristics of the unit or the immediate area.

In the future industrial land use scenario which is probable based on current land-use designation for this area, all of the soil related risks are below $1 \times 10^{-6}$.

In the future residential land use scenario, the contaminants that contributed to the risk exceeding $1 \times 10^{-6}$ from soil exposure were arsenic, beryllium, iron, OCDD, and PCB-1254. Of these, the concentrations of arsenic, beryllium, iron, and OCDD were statistically either shown to be equivalent to background levels or insignificantly elevated above background. The only remaining risk attributed to the pit soil is $2 \times 10^{-6}$ due to PCB-1254 via ingestion of produce grown on-site. The maximum concentration of PCB-1254 detected in the pit was $0.115 \mathrm{mg} / \mathrm{kg}$ and PCBs were detected in only two of 37 samples. For these reasons, soil remediation is not needed at BRP6G to be protective of human health and the environment. Potential future risks associated with the residual contamination at the unit are acceptable.

There were no remedial action-specific or location-specific ARARs relevant to establishing remedial action objectives for the BRP6G source unit. There also were no chemical-specific ARARs identified, however there is TBC guidance. TBC guidance for PCB contamination in soils is found in the Toxic Substances Control Act and EPA guidance (EPA, 1990). These TBC guidances list soil action levels of 1 ppm PCB in soils for residential use and 10-25 ppm in soils for industrial use. BRP6G is well below the residential soil action level.

One potential remedial action objective for groundwater is to ensure that all groundwater is below MCLs. The only MCL that was exceeded was for bis(2-ethylhexyl)phthalate. The maximum value detected was $6.11 \mu \mathrm{g} / \mathrm{L}$ which slightly exceed the MCL of $6 \mu \mathrm{g} / \mathrm{L}$. This value is likely not representative of the concentration of bis(2ethylhexyl)phthalate in the groundwater because a subsequent sample taken from the same well 25 days later showed a value of only $0.254 \mu \mathrm{g} / \mathrm{L}$.

An additional potential remedial action objective is for the groundwater to meet the EPA's at-thetap guidance. Lead is the only constituent to exceed this guidance. The 12/3/94 turbid sample from CBR4 had a value of $89.1 \mu \mathrm{g} / \mathrm{L}$. which exceeds the guidance value of 15 . A subsequent sample taken from the same well 25 days later measured $11.8 \mu \mathrm{g} / \mathrm{L}$.

Arsenic and beryllium both are risk-based contaminants of concern for groundwater at the BRP6G. Arsenic was found in only one of 27 groundwater samples and was not included in risk calculations based on the low frequency of detection. In addition, when the well was resampled 25 days later, arsenic was not detected. This indicates that this was an atypical value and is not representative of the actual groundwater conditions.

Beryllium was found in only one groundwater sample at levels that exceeded two times the background level for groundwater. This was from a turbid sample and likely contains higher levels of metals than a truly representative sample would contain. Beryllium is not associated with known activities in the BRP6G, but is prevalent in the 
clayey soils in the area. For these reasons, it is unlikely that the groundwater is being contaminated with beryllium from BRP6G.

For the reasons stated above, there are no remedial actions required for soil or groundwater to protect human health and the environment. The remedial action objective for BRP6G is, therefore, no remedial action.

\section{THE SELECTED REMEDY}

The selected remedy for BRP6G is No Action.

If the property is ever transferred to non-federal ownership, the U. S. Government will create a deed for the new property owner which will contain information in compliance with CERCLA 120 (h). The deed shall include notification disclosing former waste management and disposal activities as well as remedial actions taken at the site. The deed notification shall, in perpetuity, notify any potential purchaser that the property has been used for the management and disposal of construction debris and other materials, including hazardous substances. In addition, if the site is ever transferred to non-federal ownership, a survey plat of the area will be prepared, certified by a professional land surveyor, and recorded with the appropriate county agency.

This proposal is consistent with EPA guidance and is an effective use of risk management principles. The Statement of Basis/Proposed Plan provided for involvement with the community through a document review process and a public comment period. Public input is documented in the responsiveness summary in Appendix A.

\section{STATUTORY DETERMINATIONS}

Based on the BRP6G RCRA Facility Investigation/Remedial Investigation (RFI/RI) Report, the Baseline Risk Assessment (BRA), and the uncertainty analysis, the $B R P 6 G$ poses no significant risk to human health and the environment. While unit-related risk levels exceed $1 \times 10^{-6}$, a risk management decision was made to implement the No action alternative.
The selected remedy is protective of human health and the environment and complies with federal and state requirements that are legally applicable or relevant and appropriate to the remedial action. No Action will result in hazardous substances, pollutants, or contaminants remaining in the source unit.

\section{EXPLANATION OF SIGNIFICANT CHANGES}

There were no significant changes made to the Record of Decision based on comments received during the public comment period for the Statement of Basis/Proposed Plan. Comments that were received during the public comment period are addressed in Appendix A. -

\section{RESPONSIVENESS SUMMARY}

A Responsiveness Summary of the comments received during the public comment period is included in Appendix A. 


\section{REFERENCES}

DOE (U. S. Department of Energy), 1994. Public Involvement, A Plan for Savannah River Site. Savannah River Operations Office, Aiken South Carolina.

DOE, 1996. Savannah River Site Future Use Project Report. U. S. Department of Energy Savannah River Operations Office, Aiken, South Carolina, January, 1996.

EPA (U. S. Environmental Protection Agency), 1990. A Guide on Remedial Actions at Superfund Sites with PCB Contamination. Office of Emergency and Remedial Response. Directive 9355.4-01 FS, (August 1990).

EPA, 1991. OSWER Directive 9355.0-30, Role of the Baseline Risk Assessment in Superfund Remedy Selection Decisions. Office of Solid Waste and Emergency Response, (April 22, 1991).

FFA, 1993. Federal Facility Agreement for the Savannah River Site, Administrative Docket No. 89-05-FF, (Effective Date: August 16, 1993).

WSRC (Westinghouse Savannah River Company), 1995. Data Summary Report for the RFI/RI Assessment Sampling at Central Shops Burning/Rubble Pit Waste Unit. WSRC-RP95-1546, Revision 1, Westinghouse Savannah River Company, Aiken, South Carolina (March 1996).

WSRC, 1996a. RCRA Facility Investigation Remedial Investigation Report With Baseline Risk Assessment for the Central Shops Burning/Rubble Pit (63I-6G) (U), WSRC-RP95-1539, Revision 1.1, Westinghouse Savannah River Company, Aiken, South Carolina (April, 1996).
WSRC, 1996b. Statement of Basis/Proposed Plan for the Central Shops Burning/Rubble Pit (63I-6G) (U). WSRC-RP-96-142, Revision 1, Westinghouse Savannah River Company, Aiken, South Carolina (October 1996). 
Record of Decision for the Central Shops Burning/Rubble Pit (631-6G) (U)

WSRC-RP-96-873

Revision 1

Savannah River Site

Page 23 of 24

APPENDIX A

RESPONSIVENESS SUMMARY 


\section{RESPONSIVENESS SUMMARY}

The public comment period for the Statement of Basis/Proposed Plan for the Central Shops Burning/Rubble Pit (631-6G) began on December 10, 1996 and ended on January 23, 1997. The public comment period for the RCRA Permit Modification began on January 27, 1997 and ended on March 12, 1997.

\section{Public Comments}

No oral, written, phoned, or e-mailed comments were received from the public. 